\title{
Concentrations of low molecular weight carboxylic acids and carbonyl compounds in the Aegean Sea (Eastern Mediterranean) and the turnover of pyruvate
}

\author{
Ingrid Obernosterer, Gijsbert Kraay, Elisabeth de Ranitz, Gerhard J. Herndl* \\ Department of Biological Oceanography, Netherlands Institute for Sea Research (NIOZ), PO Box 59, 1790 AB Den Burg, \\ Texel, The Netherlands
}

\begin{abstract}
In situ concentrations of low molecular weight carboxylic acids and carbonyl compounds were determined in the upper $100 \mathrm{~m}$ water column in the Eastern Mediterranean Sea in September 1997. Concentrations ranged from 1 to $13 \mathrm{nM}$ for pyruvate, 1 to $11 \mathrm{nM}$ for glyoxylate and 30 to $70 \mathrm{nM}$ for glycolaldehyde. No distinct diurnal pattern in the depth distribution of carboxylic acids and carbonyl compounds was detectable. Exposure of surface water to solar radiation, however, resulted in photochemical production of acetaldehyde $\left(10 \mathrm{nmol} \mathrm{l}^{-1} \mathrm{~h}^{-1}\right)$, acetone/acrolein $\left(6 \mathrm{nmol} \mathrm{l}^{-1} \mathrm{~h}^{-1}\right)$ and pyruvate $\left(3 \mathrm{nmol} \mathrm{l}^{-1} \mathrm{~h}^{-1}\right)$. Depth profiles of the optical properties of the total organic carbon (TOC) exhibited low TOC-normalized fluorescence (excitation $350 \mathrm{~nm}$, emission $450 \mathrm{~nm}$ ) and absorbance $\left(a_{365 \mathrm{~nm}}\right.$ ) in the top $25 \mathrm{~m}$, both increasing with depth. This indicates an increasing contribution of refractory molecules to the TOC pool with depth. Uptake rates of pyruvate by heterotrophic bacterioplankton ranged

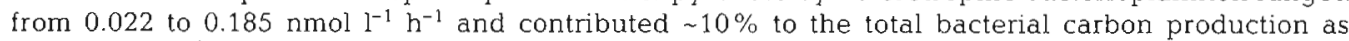
measured by $\left[{ }^{3} \mathrm{H}\right]$ leucine incorporation. Bio-assay experiments with surface water amended with either $1 \mu \mathrm{M} \mathrm{NO}_{3}, 0.4 \mu \mathrm{MPO}_{4}$ or $1 \mu \mathrm{M}$ glucose or in combination decreased pyruvate uptake as compared to the unamended control. Our results reveal that pyruvate might be an important source of carbon for bacterioplankton, with turnover times of pyruvate of 0.7 to $24 \mathrm{~d}$.
\end{abstract}

KEY WORDS: Mediterranean Sea - Bacterioplankton · Carboxylic acids · Carbonyl compounds - Ultraviolet radiation . Dissolved organic matter Pyruvate $\cdot$ Bacterial utilization

\section{INTRODUCTION}

The bulk of the organic carbon in the ocean consists of dissolved organic carbon (DOC) with a fraction of $<5 \%$ of particulate organic carbon (POC) contributing to the total organic carbon (TOC) pool (Sharp 1973, Thurman 1985, Benner 1998). This DOC pool mainly ( 60 to $80 \%$ ) consists of small, low molecular weight (LMW) carbon (<1000 Da) (Carlson et al. 1985a, Benner et al. 1992, Ogawa \& Ogura 1992, Guo et al. 1995) and only a small fraction is composed of high molecular weight (HMW) organic matter (Koike et al. 1990, Guo et al. 1995). While the large pool of LMW DOC

\footnotetext{
· Corresponding author. E-mail: herndl@nioz.nl
}

is more resistant to bacterioplankton utilization, the HMW DOC was found to be readily available for marine bacterioplankton (Amon \& Benner 1994, Guo et al. 1995).

Among the LMW DOC, however, there are also specific compounds which are readily taken up by bacterioplankton, such as free amino acids, monomeric carbohydrates and LMW carboxylic acids and carbonyl compounds. These free amino acids and LMW organic acids and carbonyl compounds are central intermediates of biochemical pathways and important products of chemical and biological degradation of organic matter. Because most of the organic acids are readily biodegradable, they represent a potentially important carbon and energy source for heterotrophic bacteria in 
seawater (Wright \& Shah 1975, Billen et al. 1980). As a consequence of efficient bacterial utilization, organic acids are present in marine waters in rather low concentrations, generally in the low nM range (Fuhrman \& Ferguson 1986, Leboulanger et al. 1997).

LMW DOC is also produced by photochemically induced cleavage from bulk DOC (Kieber \& Mopper 1987, Kieber et al. 1989, Mopper et al. 1991, Wetzel et al. 1995, Bertilsson \& Tranvik 1998), thereby rendering originally refractory DOM compounds more labile (Lindell et al. 1995, Kaiser \& Herndl 1997, Moran \& Zepp 1997). This process is to a large extent driven by ultraviolet (UV) radiation, which can penetrate the water column to considerable depth, particularly under oligotrophic conditions (Fleischmann 1989, Smith 1989).

Bacterial utilization of DOC is often limited by the availability of nitrogen or phosphorus (Zweifel et al. 1993), such as in the Mediterranean Sea, which represents a phosphorus-limited system (Krom et al. 1991, Bethoux et al. 1992, Thingstad \& Rassoulzadegan 1995). Under such P-limited conditions, even labile DOC might not be taken up efficiently by bacterioplankton and might therefore accumulate (Zweifel et al. 1993, Carlson \& Ducklow 1995, Obernosterer \& Herndl 1995). Abiotic transformation of this originally labile DOC can lead to the formation of semi-labile and eventually recalcitrant DOC (Carlson et al. 1985b, Keil \& Kirchman 1994, Benner \& Biddanda 1998, Tranvik \& Kokalj 1998).

The aim of this study was to determine the fluctuations of the in situ concentrations of carboxylic acids and carbonyl compounds in the upper $100 \mathrm{~m}$ water column in the Eastern Mediterranean Sea and to relate these fluctuations to the photochemical production of carboxylic acids and carbonyl compounds. Therefore, we followed diurnal dynamics at 2 stations and determined the photochemical production rate in $0.2 \mu \mathrm{m}$ filtered seawater. As an example of carboxylic acid utilization by bacterioplankton, the role of pyruvate as a carbon source for heterotrophic bacteria was assessed in bio-assay experiments under different nutrient conditions.

\section{MATERIAL AND METHODS}

Study sites. Samples were taken during a cruise in the South and North Aegean Sea (Eastern Mediterranean Sea) in September 1997 (Fig. 1). The stations in the South Aegean (Stns MSB1 1000 m, MSB2 1500 m; MSB7 $1295 \mathrm{~m}$ ) can be classified as oligotrophic and comprise different water masses (Atlantic, the Levantine Intermediate Water and the Eastern Mediterranean Deep Water, respectively). In contrast, some

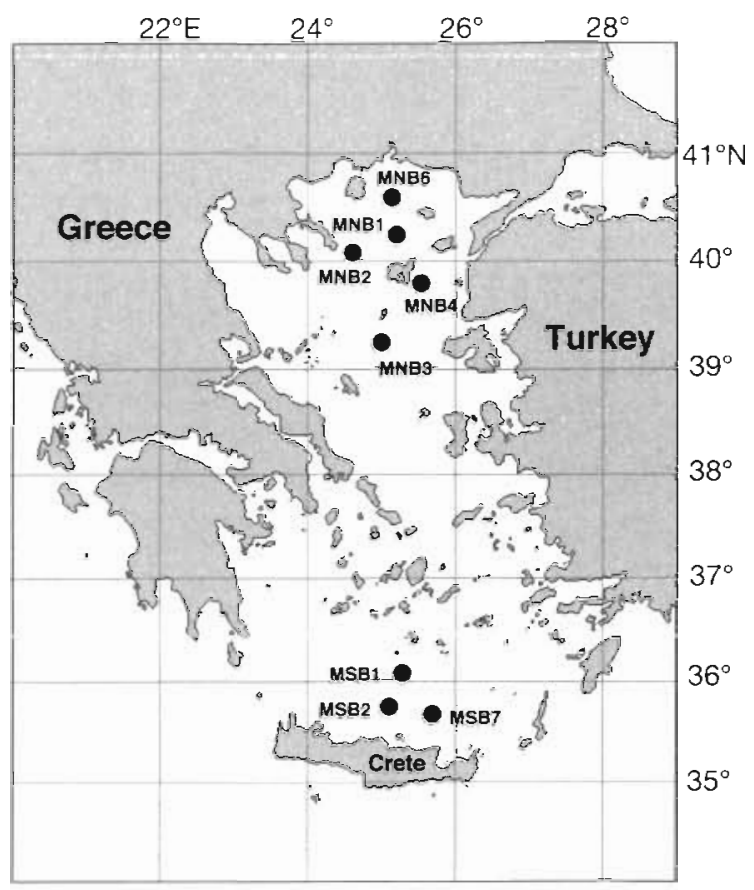

Fig. 1. Map of the South and North Aegean Sea. : sampling sites

parts of the North Aegean Sea (Stns MNB1 $700 \mathrm{~m}$, MNB2 $970 \mathrm{~m}, \mathrm{MNB} 3700 \mathrm{~m}, \mathrm{MNB} 4100 \mathrm{~m}$; MNB6 $100 \mathrm{~m}$ ) are considerably influenced by Black Sea waters entering through the Straits of Dardanelles (Theocharis et al. 1993).

Irradiance measurements. Underwater irradiation was measured at 4 distinct wavelengths in the UV-B $(305,320 \mathrm{~nm})$ and UV-A $(340,380 \mathrm{~nm})$ range as well as the integrated irradiance of the photosynthetic active radiation (PAR, 400 to $700 \mathrm{~nm}$ ) using a Profiling Ultraviolet Radiometer (Biospherical PUV-500). Irradiance measurements were done at 2 stations in the South Aegean (Stns MSB1 and MSB7) and 2 stations in the North (Stns MNB1 and MNB6) Aegean Sea (Fig. 1).

Photochemical production of carboxylic acids and carbonyl compounds. At Stn MSB2, seawater was collected from $10 \mathrm{~m}$ depth at around 11:00 h and immediately filtered through combusted Whatman GF/F filters. The filtrate was subsequently transferred to $50 \mathrm{ml}$ quartz glass tubes and exposed to surface solar radiation from $12: 00$ to $17: 30 \mathrm{~h}$. The dark control was wrapped in aluminum foil. The incubations were performed in a water bath on deck and the temperature was kept constant by a flow-through system providing surface seawater $\left(\sim 23^{\circ} \mathrm{C}\right)$. The quartz tubes were covered at both ends with Teflon foil $(200 \mu \mathrm{m}$ thick, Fluorplast, The Netherlands) soaked in $1 \mathrm{~N} \mathrm{HCl}$ and extensively rinsed with Milli- $Q$ water before use. The Teflon foil was supported by PVC holders fitted to the tube with an O-ring. Samples for carboxylic acids and car- 
bonyl compounds were taken before exposure to solar radiation, and after 1.5 and $5.5 \mathrm{~h}$. Photochemical production rates were calculated from the linear increase in carboxylic acids and carbonyl compounds over time.

Uptake experiments with ${ }^{14} \mathrm{C}$-pyruvate. At all stations, seawater samples were collected with rinsed Niskin bottles from 1 and $10 \mathrm{~m}$ depth at 07:00 $\mathrm{h}$ and around noon or at 16:00 h. Subsamples (100 ml) were transferred to acid-rinsed biological oxygen demand (BOD) bottles, leaving $\sim 20 \mathrm{ml}$ headspace, and ${ }^{14} \mathrm{C}$ pyruvate (specific activity $28 \mathrm{mCi} \mathrm{mmol}^{-1}$, Amersham) was added at a final concentration of $15 \mathrm{nM}$. Samples were incubated in triplicate with 1 formalin-killed blank at in situ temperature in the dark for $60 \mathrm{~min}$. The incubation was terminated by adding $4 \mathrm{ml}$ of concentrated formalin. The samples were then filtered onto $0.2 \mu \mathrm{m}$ cellulose nitrate filters (Millipore) and subsequently rinsed with $0.2 \mu \mathrm{m}$ filtered seawater. The filters were placed in scintillation vials and stored at $4^{\circ} \mathrm{C}$ until returning to the NIOZ within $3 \mathrm{wk}$. At the $\mathrm{NIOZ}$, the filters were dissolved in $1 \mathrm{ml}$ ethylacetate (Riedelde Haen), and $8 \mathrm{ml}$ liquid scintillation cocktail (Packard Insta-Gel plus) was added. The radioactivity was measured in a liquid scintillation counter (Wallac LKB 1211 Rackbeta) using the external standard ratio technique.

In an additional set of experiments, ${ }^{14} \mathrm{C}$-pyruvate uptake was measured under different nutrient concentrations in order to determine whether pyruvate uptake is nitrogen- or phosphate-limited and whether glucose would outcompete the uptake of pyruvate. Five different treatments (each $100 \mathrm{ml}$, in duplicate) were established: nitrogen $\left(\mathrm{NO}_{3}\right.$, final conc. $\left.1 \mu \mathrm{M}\right)$, phosphate (final conc. $0.4 \mu \mathrm{M}_{;}$in the form of $\mathrm{Na}_{2} \mathrm{HPO}_{4}$ ), or glucose (final conc. $1 \mu \mathrm{M}$ ) was added to establish the $\mathrm{N}$-, $\mathrm{P}$ - and $\mathrm{C}$-amended treatments, respectively. One treatment received all the different nutrients concomitantly and one treatment with no nutrient addition served as control. ${ }^{14} \mathrm{C}$-pyruvate addition and incubation procedures followed the protocol described above. The overall variance of the replicate samples was, on average, $15 \pm 10 \%(n=38)$, and the disintegrations per minute (dpm) in the formalin-killed controls accounted, on average, for $-30 \pm 12 \%$ of the dpm in the live treatments.

Dissolved organic matter (DOM) fluorescence and absorbance measurements. Water samples for DOM fluorescence and absorbance measurements were collected at 3 stations in the North Aegean Sea (Stns MNB1, MNB3 and MNB6; see Fig. 1). Seawater was filtered through combusted Whatman $G F / F$ filters and $10 \mathrm{ml}$ of the sample was sealed in combusted glass ampoules and stored frozen at $-20^{\circ} \mathrm{C}$. Fluorescence was measured at an excitation wavelength of $350 \mathrm{~nm}$ and an emission wavelength of $450 \mathrm{~nm}$ using a $1 \mathrm{~cm}$ quartz cuvette. The fluorometer (Hitachi F-2000) was calibrated with a quinine sulfate solution (1 QSU = $1 \mathrm{ppb}$ in $0.05 \mathrm{M} \mathrm{H}_{2} \mathrm{SO}_{4}$ ). Absorbance measurements were performed with a Spectronic Genesys 2PC spectrophotometer using a $5 \mathrm{~cm}$ quartz cuvette and Milli-Q water as a reference. In addition to absorbance spectra (250 to $500 \mathrm{~nm}$ wavelength), absorbance at 250 and $365 \mathrm{~nm}\left(\mathrm{abs}_{250 \mathrm{~nm} / 365 \mathrm{~nm}}\right)$ was measured to obtain a rough estimate of the molecular weight distribution of the DOM (Strome \& Miller 1978).

Total organic carbon. Samples for TOC were sealed in combusted glass ampoules and immediately frozen at $-20^{\circ} \mathrm{C}$. TOC concentrations were determined by the high temperature combustion (HTCO) method using a Shimadzu TOC-5000 analyzer (Benner \& Strom 1993). Standards were prepared with potassium hydrogen phthalate (Kanto Chemical Co., Inc.). Both the water blank (i.e. Milli-Q water re-distilled with $10 \mathrm{mM}$ potassium peroxide sulfate and $20 \mathrm{mM}$ o-phosphoric acid [Sigma Chemicals Co.]) and instrument blanks were assessed before and after sample analysis. Blanks typically ranged between 3.3 and $4.2 \mu \mathrm{M} \mathrm{C} \mathrm{l^{-1 }}$ and

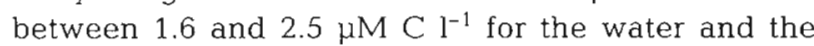
instrument, respectively. The overall analytical precision was always better than $3 \%$.

To determine the contribution of POC to the TOC pool, the organic carbon concentration in unfiltered versus filtered water samples was compared in a set of samples. Only at $5 \mathrm{~m}$ depth were carbon concentrations found to be slightly higher in the unfiltered samples as compared to the filtered samples (3 to $9 \%$, in 3 out of 7 paired comparisons; R. Sempéré pers. comm.). Occasionally higher carbon concentrations were observed in the filtered water samples, indicating possible contamination. Thus, the reported TOC concentrations also represent the DOC concentrations at these study sites

Determination of LMW carboxylic acids and carbonyl compounds. Depth profiles from the surface $100 \mathrm{~m}$ layer were sampled at 3 stations in the North Aegean Sea (Stns MNB1, MNB3 and MNB6; Fig. 1) using rinsed $10 \mathrm{l}$ Niskin bottles mounted on a CTD rosette. Sampling was done at $07: 00$ and 14:00 h at both Stn MNB1 and Stn MNB6, while at Stn MNB3 only an afternoon cast was sampled. As soon as the samples were on deck, they were tapped into acidrinsed glass bottles and immediately filtered through combusted Whatman GF/F filters. The filter holder was rinsed with $20 \mathrm{ml}$ of sample water before an aliquot was collected for analysis. The filtration procedure was performed in clean, marine air, at low pressure to avoid contamination (Mopper \& Stahovec 1986). The filtrates were sealed in combusted glass ampoules and stored frozen at $-20^{\circ} \mathrm{C}$. Carboxylic acids and carbonyl compounds were determined using a derivatization technique, based on the reaction of carboxylic acids and 
carbonyl compounds with 2,4-dinitrophenylhydrazine (DNPH) at ambient temperature to form highly UV-absorbing hydrazones. Generally, the method of Edelkraut \& Brockmann (1990) was followed using a Waters $600 \mathrm{E}$ HPLC system. To check whether freezing would introduce artifacts or alter the concentration of carboxylic acids and carbonyl compounds, comparative measurements were performed with freshly collected seawater samples that were either directly injected into the HPLC system or stored frozen for 10 to 14 d before analysis. No differences between the freshly collected samples and samples stored frozen were dectable (data not shown).

The derivatization reagent was prepared by dissolving $13 \mathrm{mg}$ of re-crystallized DNPH (Baker) in $10 \mathrm{ml}$ of a solution containing concentrated $\mathrm{HCl}$ (12 N $), M i H i-Q$ water and acetonitrile (Promochem) in the ratio 2:5:1 (v:v:v). The reagent was freshly prepared daily using combusted glassware. The reagent solution was kept tightly capped and wrapped in aluminum foil at $4^{\circ} \mathrm{C}$.

After thawing and mixing the samples, a $10 \mathrm{ml}$ subsample was immediately derivatized by adding $100 \mu \mathrm{l}$ of the DNPH reagent. The mixture was gently stirred and incubated at room temperature in the dark for 45 min. Blanks were prepared by adding $100 \mu \mathrm{DNPH}$ reagent to $10 \mathrm{ml}$ Milli- $Q$ water followed by immediate injection into the HPLC system. For standards prepared in Milli- $Q$ water, Milli- $Q$ blanks were incubated in the dark for $45 \mathrm{~min}$.

The samples were injected through a Rheodyne (7010) valve into a $2 \mathrm{ml}$ sample loop. After injection, the sample was pumped with a Waters M-45 standalone-pump onto a $50 \times 4 \mathrm{~mm} \mathrm{RP-18}$ enrichment column with a flow rate of $1 \mathrm{ml} \mathrm{min} \mathrm{min}^{-1}$ for $4 \mathrm{~min}$. Prior to sample injection, the enrichment column was rinsed with Milli- $Q$ water at the same flow rate for $4 \mathrm{~min}$. The column was then connected to the Rheodyne (7125) injection valve of the HPLC system. The HPLC system consisted of a Waters $600 \mathrm{E}$ gradient module with a system controller and a photodiode array detector (model 991) set at $360 \mathrm{~nm}$ wavelength. The column $(250 \times 4 \mathrm{~mm})$ was packed with Nucleosil 120-C18 $5 \mathrm{~m}$ (Machery-Nagel, Düren, Germany). Two mobile phases were used for the separation of the hydrazones: (1) acetonitril:methanol:buffer (5 $\mathrm{mM} \mathrm{KH}_{2} \mathrm{PO}_{4}$ ), 1:1.4:6 (v:v:v); (2) acetonitril:buffer, 3:2 (v:v).

Concentrations of the organic acids were calculated by linear regression analysis; calibration plots were generated by standard additions to Milli-Q water (for pyruvate, glyoxylate and glycolaldehyde; Fluka BioChemica). For acetaldehyde and acetone/acrolein, an aldehyde/ketone DNPH working standard 13 kit made up in acetonitinile (Rádiañ Intemationail) was used. It was not possible to separate acetone from acrolein by our method, thus we subsequently refer to acetone/acrolein. The stock solutions were serially diluted in Milli- $Q$ water to concentrations expected in seawater (10 to $100 \mathrm{nM}$ ). The HPLC chromatograms were further analyzed with a Waters 990 program.

Statistical analysis. Kruskal-Wallis 1-way ANOVA with a multiple post hoc (Tukey) was used to test treatment effects on variables. Statistics were performed with SYSTAT 5.2 (Wilkinson 1990).

\section{RESULTS}

\section{Concentration of TOC and optical properties of DOM}

In the upper $100 \mathrm{~m}$ water layer, TOC concentrations ranged from 54 to $87 \mu \mathrm{M} \mathrm{C}$ in the South Aegean and from 52 to $144 \mu \mathrm{MC}$ in the North Aegean Sea. At 3 stations (Stns MNB1, MNB3 and MNB6; Fig. 1), depth
Fig. 2. Depth profiles of (a) total organic carbon (TOC) concentrations and fluorescence (excitation $350 \mathrm{~nm}$, emission $450 \mathrm{~nm}$ ) and (b) absorbance characteristics at Stn MNB6 in the North Aegean Sea. Fluorescence is given in TOC-normalized quinine sulfate units (QSU). All data refer to samples collected at 14:00 h
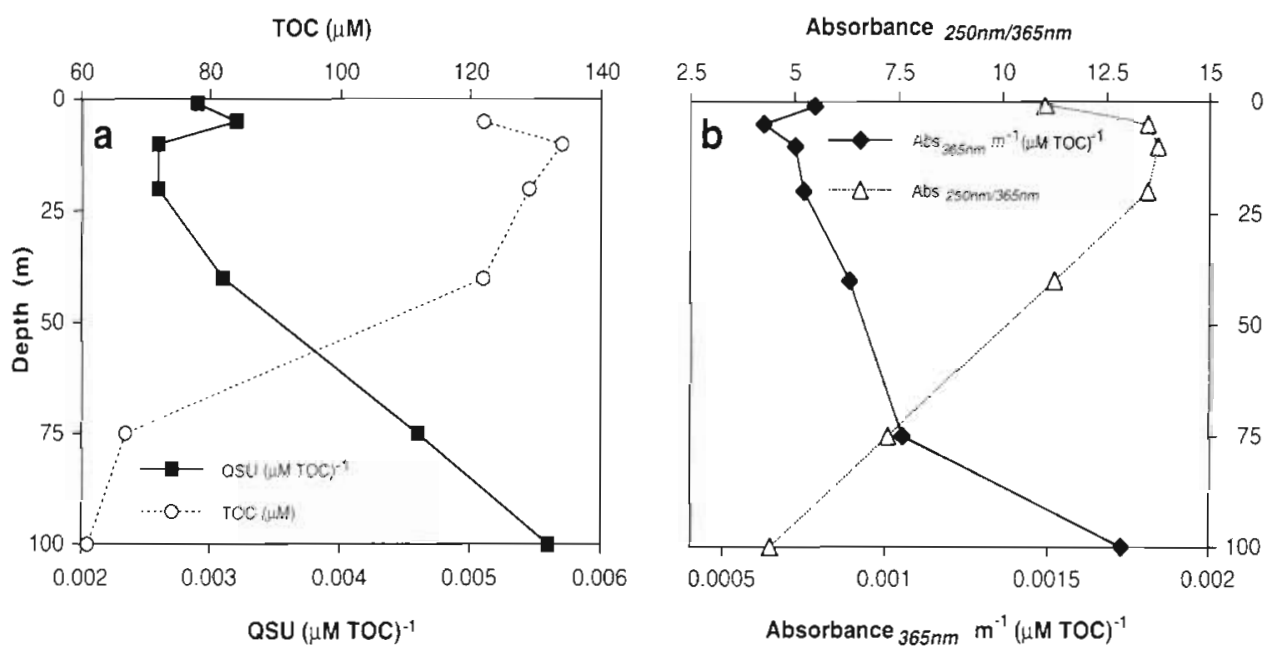


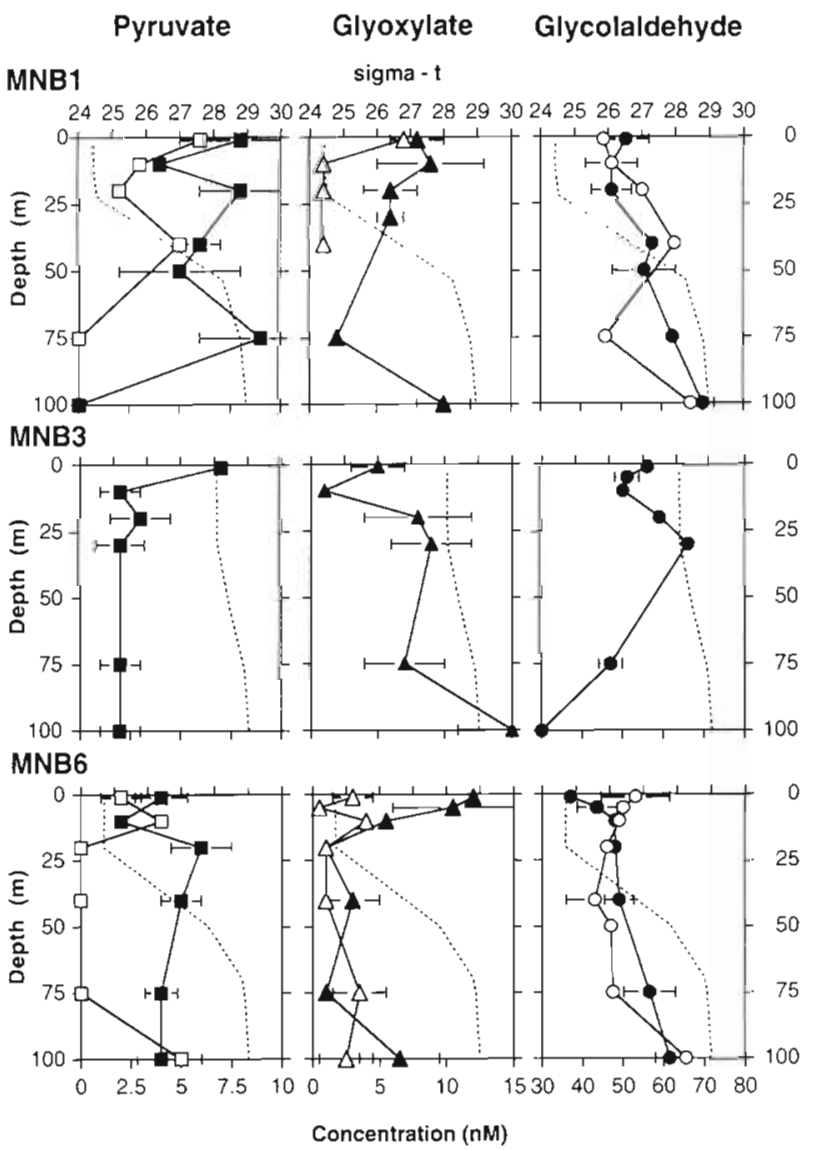

Fig. 3. Depth profiles of pyruvate, glyoxylate and glycolaldehyde concentrations (in $\mathrm{nM}$ ) (-) and sigma-t (--.-) at Stns MNB1, MNB3 and MNB6 in the North Aegean Sea collected at $07: 00 \mathrm{~h}$ (open symbols) and at 14:00 h (solid symbols). Symbols represent means of duplicate measurements \pm percent mean deviation

profiles of DOM fluorescence and absorbance and concentrations of carboxylic acids and carbonyl compounds were determined (Figs. $2 \& 3$ ). At these stations, the water column (as indicated by sigma- $t$ values; see Fig. 3) was characterized by a surface mixed layer (down to $25 \mathrm{~m}$ depth). The observed chlorophyll maximum layer was at 50 $m$ depth at Stns MNB1 and MNB6 and at $100 \mathrm{~m}$ depth at Stn MNB3. A representative depth profile of TOCnormalized fluorescence is shown in Fig. 2a and the TOC-normalized absorbance at $365 \mathrm{~nm}$ from Stn MNB6 in Fig. 2b. A similar pattern was observed at Stns MNB1 and MNB3. Both TOCnormalized fluorescence and absorbance were lowest in the uppermost 25 $m$ water layer and increased with depth. Concentrations of TOC were highest close to the surface and de- creased with depth. Similar to the TOC profile, the absorbance ratio $\mathrm{abs}_{250 \mathrm{~nm} / 36 . \mathrm{nm}}$ was highest in the uppermost $25 \mathrm{~m}$ water layer and decreased with depth. Irradiance measurements throughout the water column of the different stations in the North Aegean Sea indicated that $10 \%$ of the surface solar radiation of the UV-B range ( 280 to $320 \mathrm{~nm}$ ) reached 4 to $7 \mathrm{~m}$ depth; for the UV-A range $(320$ to $380 \mathrm{~nm})$ the $10 \%$ radiation depth was between 9 and $19 \mathrm{~m}$ and for PAR between 27 and $32 \mathrm{~m}$ (Table 1). In the South Aegean Sea, 10\% radiation depths were found to be considerably deeper, ranging between 9 and $15 \mathrm{~m}$ depth for the UV$B$ range and between 19 and $39 \mathrm{~m}$ depth in the UV-A range (Table 1).

\section{Depth distribution of carboxylic acids and carbonyl compounds}

The concentration of several species of carboxylic acids and carbonyl compounds were determined at Stns MNB1, MNB3 and MNB6 in the North Aegean Sea. The 3 most dominant carboxylic acids and carbonyl compounds detected were pyruvate, glyoxylate and glycolaldehyde (Fig. 3). In a few samples, acetaldehyde and acetone/acrolein were detected at low nanomolar concentrations as well, but, due to their inconsistent presence, these data are not presented here. The distribution of the dominant carboxylic acids and carbonyl compounds did not follow a distinct pattern over the top $100 \mathrm{~m}$ water column. Pyruvate and glyoxylate were present in the low nanomolar range ( 1 to $8 \mathrm{nM}$ for pyruvate and 1 to $11 \mathrm{nM}$ for glyoxylate), while concentrations of glycolaldehyde varied between 30 and $70 \mathrm{nM}$. At Stns MNB1 and MNB6, samples were collected at 07:00 and at 14:00 h in order to determine possible diurnal variations in the concentration of carboxylic acids and carbonyl compounds (Fig. 3). At both stations, glyoxylate exhibited higher concentrations in the afternoon as compared to the morning in the upper $25 \mathrm{~m}$ layer, and pyruvate concentrations

Table 1. Attenuation coefficients $\left(\mathrm{Kd} \mathrm{m}^{-1}\right)$ of 4 distinct wavelengths in the UV-B $(305 \mathrm{~nm}, 320 \mathrm{~nm})$ and UV-A $(340 \mathrm{~nm}, 380 \mathrm{~nm})$ range and photosynthetic active radiation (PAR, 400 to $700 \mathrm{~nm}$ ) measured in the South and North Aegean Sea. All irradiation measurements were performed on cloudless days around noon

\begin{tabular}{|lccccc|}
\hline Stn & $\mathrm{Kd}_{305}\left(\mathrm{~m}^{-1}\right)$ & $\mathrm{Kd}_{320}\left(\mathrm{~m}^{-1}\right)$ & $\mathrm{Kd}_{340}\left(\mathrm{~m}^{-1}\right)$ & $\mathrm{Kd}_{380}\left(\mathrm{~m}^{-1}\right)$ & $\mathrm{Kd}_{\mathrm{PAR}}\left(\mathrm{m}^{-1}\right)$ \\
\hline South Aegean & & & & & \\
MSB1 & 0.245 & 0.164 & 0.121 & 0.115 & 0.086 \\
MSB7 & 0.215 & 0.157 & 0.106 & 0.059 & 0.072 \\
North Aegean & & & & & \\
MNB1 & 0.528 & 0.333 & 0.233 & 0.122 & 0.080 \\
MNB6 & 0.399 & 0.350 & 0.266 & 0.122 & 0.068 \\
\hline
\end{tabular}


were higher throughout the entire water column in the afternoon. No such pattern could be observed for glycolaldehyde.

\section{Production of carboxylic acids and carbonyl compounds in filtered seawater under natural solar radiation}

To determine the photochemical production of carboxylic acids and carbonyl compounds, freshly collected Whatman GF/F filtered water from $10 \mathrm{~m}$ depth was exposed to surface solar radiation (TOC concentration $=82 \mu \mathrm{M})$. Acetaldehyde, acetone/acrolein and pyruvate were photochemically produced during the $5.5 \mathrm{~h}$ incubation period (Fig. 4a). The photochenical production was highest for acetaldehyde $\left(10 \mathrm{nmol} \mathrm{l}^{-1}\right.$ $\mathrm{h}^{-1}$ ). Acetone/acrolein and pyruvate were produced at

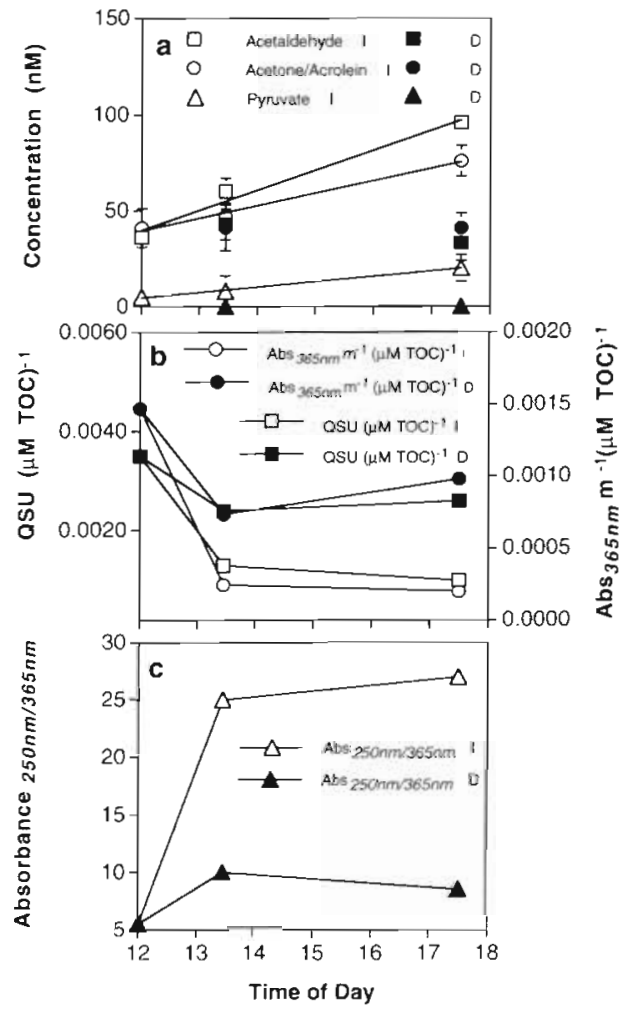

Fig. 4. Time course of (a) photochemical production of carboxylic acids and carbonyl compounds, (b) fluorescence and absorbance ( $\mathrm{abs}_{36 \mathrm{snm}}$ ) normalized to TOC and (c) absorbance ratio $\left(\mathrm{abs}_{250 \mathrm{rm} / 355 \mathrm{~mm}}\right)$ upon irradiation of GF/F-filtered seawater from $10 \mathrm{~m}$ depth. Carboxylic acids and carbonyl compounds produced during exposure to surface solar radiation are acetaldehyde $\left(\square: y=10.187 x+38.53, x^{2}=0.99\right)$, acetone/acrolein (O: $\left.y=6.288 x+38.947, \mathrm{r}^{2}=0.98\right)$ and pyruvate $\left(\Delta: y=2.778 x-28.774, \mathrm{r}^{2}=0.99\right)$ with respective dark controls $(\boldsymbol{\square}, \mathbf{A})$. Fluorescence $(b)$ is given in TOC-normalized QSU. I: irradiated, D: dark rates of 6 and 3 nmol $\mathrm{l}^{-1} \mathrm{~h}^{-1}$, respectively. Simultaneously, the fluorescence of the DOM decreased by $\sim 50 \%$, its absorbance at $365 \mathrm{~nm}$ decreased to $70 \%$ of the corresponding dark value (Fig. $4 \mathrm{~b}$ ), while the ratio $\mathrm{abs}_{250 \mathrm{~nm} / 365 \mathrm{~nm}}$ increased $\sim 5$-fold (Fig. 4c).

\section{Uptake of ${ }^{14} \mathrm{C}$-pyruvate by bacterioplankton}

To evaluate the importance of pyruvate as a substrate for bacterioplankton, ${ }^{14} \mathrm{C}$-labeled pyruvate was added to unfiltered seawater samples and its uptake measured during short-term incubations in the dark (Table 2). In the South Aegean, pyruvate uptake rates ranged from 0.022 to $0.071 \mathrm{nmol} \mathrm{l}^{-1} \mathrm{~h}^{-1}(\mathrm{n}=7)$ and in the Nurin Aegedn from 0.047 to 0.185 nmol $^{-1} \mathrm{~h}^{-1}$ $\left(\mathrm{n}=12\right.$ ). No consistent diurnal differences in ${ }^{14} \mathrm{C}$-pyruvate uptake by bacterioplankton were detectable; however, there was a tendency of higher ${ }^{14} \mathrm{C}$-pyruvate uptake around midday and later in the afternoon as compared to the early morning (Table 2). No relationship was found between the in situ pyruvate concentration and the uptake rate of ${ }^{14} \mathrm{C}$-pyruvate, indicating that the $15 \mathrm{nM}$ addition of radiolabeled ${ }^{14} \mathrm{C}$-pyruvate represented a saturating concentration.

\section{Uptake of ${ }^{14} \mathrm{C}$-pyruvate under different nutrient additions}

${ }^{14} \mathrm{C}$-pyruvate uptake measured in seawater amended with either phosphate or glucose decreased as compared to the unamended seawater. Inorganic nitrogen had no pronounced effect on ${ }^{14} \mathrm{C}$-pyruvate uptake (Fig. 5). The decrease in uptake of pyruvate upon addition of phosphate was significant only at Stns MSB2 and MNB3 (ANOVA, $p \leq 0.05$ ) (Fig. 5). Simultaneous addition of all nutrients usually increased the pyruvate uptake as compared to the treatments with phosphate or glucose added separately; however, pyruvate uptake was still lower, though not significantly, as compared to the unamended control.

\section{DISCUSSION}

Phytoplankton production is the main source of DOC in oceanic environments (Lee \& Wakeham 1988), supporting heterotrophic bacteria directly (via excretion and cell lysis) or indirectly (via sloppy feeding) with organic matter (Lampert 1978, Lancelot 1979). The carboxylic acids and carbonyl compounds determined in this study are partly produced directly by phytoplankton (Gagosian \& Lee 1981) and partly indirectly by photochemical transformation of DOM. Optical properties 
Table 2. In situ pyruvate concentrations (nM), pyruvate uptake ( $\mathrm{nmol} \mathrm{l^{-1 }} \mathrm{h}^{-1}$ ) and pyruvate turnover time (d) in the South and North Aegean Sea. Turnover time was calculated from ${ }^{14} \mathrm{C}$-pyruvate uptake and the in situ pyruvate concentration; the in situ pyruvate concentrations were amended with $15 \mathrm{nM}$ (final conc.) ${ }^{14} \mathrm{C}$-pyruvate. Values are means of duplicate measurements (percent mean deviation $\leq 20 \%$ ). nd: not detectable

\begin{tabular}{|c|c|c|c|c|c|c|c|c|c|c|}
\hline \multirow[t]{2}{*}{ Stn } & \multirow[t]{2}{*}{$\begin{array}{l}\text { Depth } \\
(\mathrm{m})\end{array}$} & \multicolumn{3}{|c|}{$\begin{array}{l}\text { In situ pyruvate concentration } \\
\qquad(\mathrm{nM})\end{array}$} & \multicolumn{3}{|c|}{$\begin{array}{c}{ }^{14} \mathrm{C} \text {-pyruvate uptake } \\
\left(\text { nmol } \mathrm{l}^{-1} \mathrm{~h}^{-1}\right)\end{array}$} & \multicolumn{3}{|c|}{$\begin{array}{l}\text { Pyruvate turnover time } \\
\text { (d) }\end{array}$} \\
\hline & & $07: 00 \mathrm{~h}$ & $12: 00 \mathrm{~h}$ & $16: 00 \mathrm{~h}$ & $07: 00 \mathrm{~h}$ & $12: 00 \mathrm{~h}$ & $16: 00 \mathrm{~h}$ & $07: 00 \mathrm{~h}$ & $12: 00 \mathrm{~h}$ & $16: 00 \mathrm{~h}$ \\
\hline \multicolumn{11}{|c|}{ South Aegean } \\
\hline \multirow{2}{*}{ MSB1 } & 1 & & & nd & & & 0.030 & & & \\
\hline & 10 & & & nd & & & 0.059 & & & \\
\hline MSB2 & 5 & & nd & & & 0.032 & & & & \\
\hline \multirow{2}{*}{ MSB7 } & 1 & nd & 13 & & 0.026 & 0.022 & & & 24.2 & \\
\hline & 10 & nd & 10 & & 0.057 & 0.071 & & & 5.70 & \\
\hline \multicolumn{11}{|c|}{ North Aegean } \\
\hline \multirow{2}{*}{ MNB1 } & 1 & 6 & & 10 & 0.098 & & 0.157 & 2.6 & & 2.7 \\
\hline & 10 & 3 & & 4 & 0.064 & & 0.175 & 2.0 & & 1.0 \\
\hline MNB2 & 10 & & & 4 & & & 0.185 & & & 0.9 \\
\hline MNB3 & 5 & & & 7 & & & 0.077 & & & 3.8 \\
\hline \multirow[t]{2}{*}{ MNB4 } & 1 & & 11 & & & 0.047 & & & 10.5 & \\
\hline & 10 & & 7 & & & 0.150 & & & 2.1 & \\
\hline \multirow[t]{2}{*}{ MNB6 } & 1 & 7 & & 4 & 0.063 & & 0.106 & 4.7 & & 1.6 \\
\hline & 10 & 7 & & 2 & 0.101 & & 0.099 & 2.9 & & 0.7 \\
\hline
\end{tabular}

of the TOC pool in the North Aegean Sea changed considerably with depth (Fig. 2). The low fluorescence and absorbance in the uppermost $25 \mathrm{~m}$ water layer as compared to subpycnocline waters strongly indicate exposure of DOM to solar radiation, in particular to UV radiation. In the North Aegean Sea, UV radiation was found to penetrate to $20 \mathrm{~m}$ depth at significant levels.

Pyruvate is a central biochemical intermediate of anabolic and catabolic metabolism. In situ concentrations of pyruvate have been reported to range from 0.2 to $12 \mathrm{nM}$ at oligotrophic and coastal sites (Kieber \& Mopper 1987, Kieber et al. 1989, Mopper et al. 1991). In the North Aegean Sea, pyruvate concentrations varied between 1 and $13 \mathrm{nM}$ throughout the upper $100 \mathrm{~m}$ water column. Although several studies point to photochemical formation of pyruvate (Kieber \& Mopper 1987, Kieber et al. 1989, Mopper et al. 1991, this study), its depth distribution does not follow a distinct temporal or spatial pattern. Therefore, it is likely that biological processes determine the concentration pattern of pyruvate in the water column.
Glyoxylate is produced by biological photorespiration, which might be the source of high concentrations of glyoxylate in surface waters (Wright \& Shah 1975 , Billen et al. 1980). Variations in the concentration of glyoxylate in the water column may result from the release of this compound by phytoplankton and uptake by heterotrophic microorganisms using the glyoxylate cycle. The importance of this pathway in marine organisms, however, is unknown. Kieber \& Mopper (1987) report glyoxylate concentrations in the range of 1 to $3 \mathrm{nM}$ in the upper $100 \mathrm{~m}$ water layer for several oceanic stations. In the North Aegean Sea, concentrations ranged from 1 to $11 \mathrm{nM}$ in the surface $100 \mathrm{~m}$ water layer. At Stns MNB1 and MNB6, generally higher glyoxylate concentrations were found in the afternoon as compared to the early morning. This increase was particularly pronounced in the top $25 \mathrm{~m}$ water layer (Fig. 3). This increase in the concentration of glyoxylate in surface waters in the afternoon could, at least to a certain extent, result from photochemical formation (Kieber \& Mopper 1987).
Fig. 5. Uptake of ${ }^{14} \mathrm{C}$-pyruvate (mol bacterium ${ }^{-1} \mathrm{~h}^{-1}$ ) under different nutrient conditions at 4 stations in the Aegean Sea. Columns show mean values of duplicate measurements \pm percent mean deviation
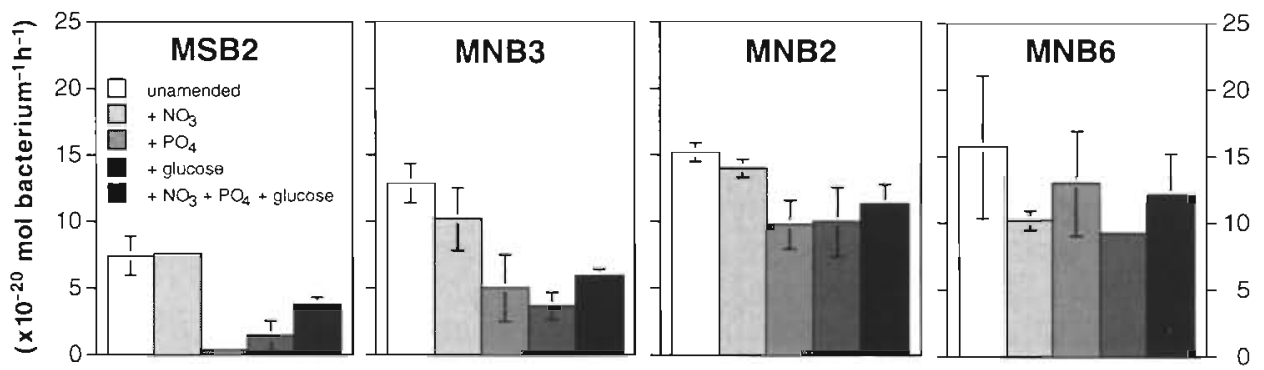
We detected the carbonyl compound glycolaldehyde in cultures of Emiliania huxleyi (Obernosterer et al. unpubl.), thus we assume that this compound, as well as a variety of other simple aldehydes, originate from phytoplankton production.

\section{Photochemical production of carboxylic acids and carbonyl compounds}

Acetaldehyde, acetone/acrolein and pyruvate were produced during exposure to solar radiation (Fig. 4a). Earlier studies on the photochemical formation of carboxylic acids and carbonyl compounds under natural sunlight report rates of 1 to $2 \mathrm{nmol} \mathrm{l}^{-1} \mathrm{~h}^{-1}$ for acetuldehyde (Mopper \& Stahovec 1986, Mopper et al. 1991) and a range of 0.6 to $6 \mathrm{nmol}^{-1} \mathrm{~h}^{-1}$ for pyruvate for several coastal and oligotrophic oceanic stations (Kieber et al. 1989, Mopper et al. 1991). Our

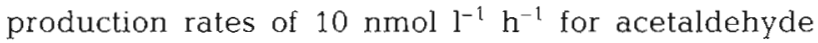
and $3 \mathrm{nmol} \mathrm{l}^{-1} \mathrm{~h}^{-1}$ for pyruvate (Fig. 4a) are therefore in the range of previously reported photochemical production rates. Simultaneous changes in the optical properties of the radiation-exposed DOM, such as loss of fluorescence and absorbance (Fig. 4b,c), also indicate that the DOM present in the surface waters at our study sites can be regarded as photochemically reactive. It is interesting to note that the production of carboxylic acids and carbonyl compounds from DOM was linear over the exposure period while fluorescence and absorbance rapidly declined over $1.5 \mathrm{~h}$ and leveled off subsequently. This indicates that the change in optical properties of the DOM is not linearly correlated with the formation of carboxylic acids and carbonyl compounds.

\section{Uptake of ${ }^{14} \mathrm{C}$-pyruvate}

In our study, biological uptake rates of pyruvate

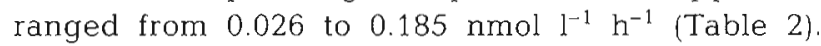
Uptake of pyruvate was markedly lower in the South Aegean as compared to the North Aegean Sea; this pattern was also found for the bacterial carbon production as measured by $\left[{ }^{3} \mathrm{H}\right]$-leucine incorporation at these stations (Christaki et al. 1999). We estimated that the sum of the concentrations of carboxylic acids and carbonyl compounds contributes only $\sim 0.13 \%$ to the TOC concentration in the North Aegean Sea and pyruvate carbon alone would account for only $\sim 0.015 \%$ of the TOC pool. Based on our results from the ${ }^{14} \mathrm{C}$-pyruvate uptake experiment, pyruvate-carbon uptake might account for as much as 7 and $14 \%$ of total bacterial carbon production (as measured by $\left[{ }^{3} \mathrm{H}\right]$-leucine incorporation) in the South and North
Aegean Sea, respectively. Our ${ }^{14} \mathrm{C}$-pyruvate uptake rates are not corrected for respiration, thus this percentage is probably an overestimation. If we assume that the overall growth efficiency of $30 \%$ is also valid for pyruvate uptake, pyruvate contribution to overall bacterial carbon production would still be 2.1 and $4.2 \%$ and therefore much higher than the contribution of pyruvate to the bulk TOC content. This estimate is similar to that of Kieber et al. (1989), who calculated that 2 to $4 \%$ of the total bacterial carbon production can be met by pyruvate. However, since we did not measure the respiration of pyruvate, the above-given values can only be regarded as a rough estimate. Bertilsson \& Tranvik (1998), for example, report considerable differences in the incorporated fractions of carboxylic acid-carbon, amounting to $\sim 2 \%$ for formic acid and $\sim 78 \%$ for malonic and acetic acid.

As indicated in Fig. 6, bacterial growth efficiency on LMW organic acids might be dependent on the overall bacterial activity. Cell-specific maintenance requirements appear to be higher in oligotrophic areas with low concentrations of substrates and nutrients (del Giorgio \& Cole 1998). Under conditions of reduced bacterial activity, like in oligotrophic environments, carboxylic acids among other LMW C-substrates might preferantially be used as an energy source, while in more eutrophic environments (as indicated by higher TOC concentrations in Fig. 6) these substrates can be more efficiently used for biomass synthesis. Thus, the relative contribution of pyruvate as a carbon source becomes more important as bacterial metabolism increases. The measured bacterial uptake rates of ${ }^{14} \mathrm{C}$ pyruvate result in pyruvate turnover times of 6 to $24 \mathrm{~d}$ in the South Aegean and of 0.7 to $10 \mathrm{~d}$ in the North Aegean Sea (Table 2).

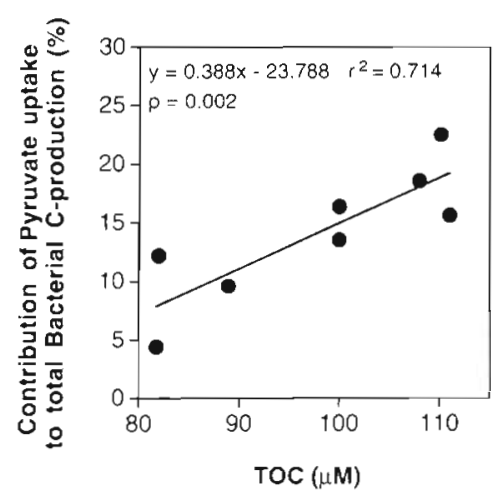

Fig. 6. Contribution of pyruvate-carbon uptake to total bacterial carbon production as measured by $\left.{ }^{3} \mathrm{H}\right]$-leucine incorporation (\%) depending on total organic carbon (TOC. $\mu \mathrm{M}$ ) concentration. Data from all sites are pooled 


\section{Uptake of ${ }^{14} \mathrm{C}$-pyruvate under different nutrient conditions}

Uptake of ${ }^{14} \mathrm{C}$-pyruvate decreased upon addition of phosphate and glucose (Fig. 5). This effect was more pronounced at Stns MSB2 and MNB3, where the TOC concentrations were lower as compared to Stns MNB2 and MNB6. Under prevailing P-limited conditions typical for the Mediterranean Sea (Krom et al. 1991, Thingstad \& Rassoulzadegan 1995), the bacterial community might be adapted to low phosphate concentrations and therefore exhibit a high capacity for phosphate uptake. At increased external phosphate concentrations, bacterioplankton might also accumulate phosphate inside the cells, which might result in a decrease of the internal $\mathrm{pH}$ due to the proton-coupled transport of phosphate (van Veen 1994). Bacterial metabolism might consequently be negatively affected by acidic internal pH values (Poolman et al. 1987). Furthermore, the proton motive force might induce competitive uptake of phosphate and other small molecules, such as pyruvate.

In the glucose-amended samples, the final concentration of glucose was $\sim 100$ times higher than the pyruvate concentration. This dilution of pyruvate-carbon only partly explains the decrease in pyruvate uptake. Glucose addition, however, might also induce 2 processes that subsequently decrease the uptake of other carbon substrates: First, catabolite repression is one mechanism decreasing pyruvate uptake in Escherichia coli by decreasing the intracellular concentration of cyclic adenosinemonophosphate (AMP) required for enzyme induction (Gottschalk 1986). Second, the inducer exclusion mechanism which activates an enzyme that directly inhibits the uptake of carbon compounds might, to some extent, be responsible for the decrease in pyruvate uptake (Gottschalk 1986). Still, even very high glucose concentrations obviously do not fully outcompete pyruvate uptake.

The photochemical production rate of pyruvate measured under surface solar radiation (Fig. 4a) is, on an hourly basis, $\sim 100$-fold higher than its biological uptake. If this comparison is done on a daily basis (given a total daylight period of $8 \mathrm{~h}$ ), photochemical production of pyruvate is still -30 times higher than its biological consumption. This imbalance between photochemical production and biological consumption is considerably higher than those reported on an hourly basis by Bertilsson \& Tranvik (1998) ( 10-fold) and Kieber et al. (1989) ( 3 -fold). Photochemical formation rates are generally measured in particle-free water at surface solar radiation. In situ photochemical formation rates will rapidly decrease with depth due to exponentially decreasing irradiation levels. Furthermore, abiotic processes, such as adsorption of LMW organic compounds onto colloidal DOM or particle surfaces might at least to some extent decrease their in situ concentration in the dissolved form (Baskaran \& Santschi 1993, Martin et al. 1995, Moran et al. 1996). On the other hand, mixing processes might rapidly transport photoproducts from the water layers where they are generated to deeper layers. All these processes will probably result in a much lower in situ net accumulation of photochemically generated compounds and therefore reduce the large imbalance between photochemical production and biological consumption processes.

However, the above-described processes probably cannot fully explain the observed imbalance between photochemical production and biological consumption of pyruvate. Thus, the overall fate of carboxylic acids and carbonyl compounds in the oceanic environment still remains to be solved.

Acknowledgements. We thank the captain and the crew of the 'Aegaeo' for their cooperation and assistance, and the scientists in charge for providing CTD data. R. Sempéré and F. van Wambeke are gratefully acknowledged for providing data on TOC concentrations and bacterial production measurements, respectively. I. Kolar excellently carried out DOC analyses. We also thank B. Reitner for excellent technical assistance. We are grateful to 2 anonymous reviewers for constructive comments on an earlier version of this manuscript. This work was funded by the CEC Marine Science and Technology program (MATER project MAS3-CT96-0051). This work is in partial fulfillment of the requirements for a $\mathrm{PhD}$ degree from the University of Groningen by I.O. This is publication no. 3435 of the NIOZ and contribution no. MTPII-MATER/041.

\section{LITERATURE CITED}

Amon RMW, Benner R (1994) Rapid cycling of high-molecular-weight dissolved organic matter in the ocean. Nature 369:549-552

Baskaran M, Santschi PH (1993) The role of particles and colloids in the transport of radionucleids in coastal environments of Texas. Mar Chem 43:95-114

Benner RH (1998) Cycling of organic matter in the ocean. In Hessen DO, Tranvik LJ (eds) Aquatic humic substances. Springer, Heidelberg, p 317-331

Benner R, Biddanda B (1998) Photochemical transformations of surface and deep marine dissolved organic matter: effects on bacterial growth. Limnol Oceanogr 43:1373-1378

Benner R, Strom M (1993) A critical evaluation of the analytical blank associated with DOC measurements by hightemperature catalytic oxidation. Mar Chem 41:153-160

Benner R, Pakulski JD, McCarthy M, Hedges JI, Hatcher PC (1992) Bulk chemical characteristics of dissolved organic matter in the ocean. Science 255:1561-1564

Bertilsson S, Tranvik LJ (1998) Photochemically produced carboxylic acids as substrates for freshwater bacterioplankton. Limnol Oceanogr 43:885-895

Bethoux JP, Morin P, Madec C, Gentili B (1992) Phosphorus and nitrogen behaviour in the Mediterranean Sea. DeepSea Res 39:1641-1654

Billen G, Joiris C, Wijnant J, Gillain G (1980) Concentration and microbiological utilization of small organic molecules in the Scheldt Estuary, the Belgian Coastal Zone of the 
North Sea and the English Channel. Estuar Coast Mar Sci 11:279-294

Carlson CA, Ducklow HW (1995) Dissolved organic carbon in the upper ocean of the central equatorial Pacific Ocean, 1992: daily and finescale vertical variations. Deep-Sea Res II 42:639-656

Carlson DJ, Brann ML, Mague TH, Mayer LM (1985a) Molecular weight distribution of dissolved organic materials in seawater determined by ultrafiltration: a re-examination. Mar Chem 16:155-171

Carlson DJ, Mayer LM, Brann ML, Mague TH (1985b) Binding of monomeric organic compounds to macromolecular dissolved organic matter in seawater. Mar Chem 16: 141-15.3

Christaki U, van Wambeke F, Dolan JR (1999) Nanoflagellates (mixotrophs, heterotrophs and autotrophs) in the oligotrophic eastern Mediterranean: standing stocks, bacterivory and relationships with bacterial production. Mar Ecol Prog Ser 181:297-307

del Giorrin PA. Cole .T.T (1998) Rarterial growth efficiency in natural aquatic systems. Annu Rev Ecol Syst 29:503-541

Edelkraut F, Brockmann U (1990) Simultaneous determination of carboxylic acids and carbonyl compounds in estuaries by HPLC. Chromatographia 30:432-435

Fleischmann EM (1989) The measurement and penetration of ultraviolet radiation into tropical marine water. Limnol Oceanogr 34:1623-1629

Fuhrman J, Ferguson RL (1986) Nanomolar concentrations and rapid turnover of dissolved free amino acids in seawater: agreement between chemical and microbiological measurements. Mar Ecol Prog Ser 33:237-242

Gagosian RB, Lee C (1981) Processes controlling the distribution of biogenic organic compounds in seawater. In: Duursma EK, Dawson R (eds) Marine organic chemistry. Elsevier Scientific, Amsterdam, p 91-123

Gottschalk G (1986) Regulation of bacterial metabolism. In: Gottschalk $G$ (ed) Bacterial metabolism. Springer, New York, p 178-207

Guo L, Santschi PH, Warnken KW (1995) Dynamics of dissolved organic carbon (DOC) in oceanic environments. Limnol Oceanogr 40:1392-1403

Kaiser E, Herndl GJ (1997) Rapid recovery of marine bacterioplankton activity after inhibition by UV radiation in coastal waters. Appl Environ Microbiol 63:4026-4031

Keil RG, Kirchman DL (1994) Abiotic transformation of labile protein to refractory protein in sea water. Mar Chem 45: $187-196$

Kieber DJ, Mopper K (1987) Photochemical formation of glyoxylic and pyruvic acids in seawater. Mar Chem 21:135-149

Kieber DJ, Daniel JMr Mopper K (1989) Photochemical source of biological substrates in sea water: implications for carbon cycling. Nature 341:637-639

Koike I, Shigemitsu H, Kazuki T, Kazuhiro K (1990) Role of submicrometre particles in the ocean. Nature 345:242-244

Krom MD, Kress N. Brenner S, Gordon LI (1991) Phosphorus limitation of primary productivity in the eastern Mediterranean Sea. Limnol Oceanogr 36:424-432

Lampert W (1978) Release of dissolved organic carbon by grazing zooplankton. Limnol Oceanogr 23:831-834

Lancelot C (1979) Gross excretion rates of natural marine phytoplankton and heterotrophic uptake of excreted products in the southern North Sea, as determined by short-term kinetics Mar Ecol Prog Ser 1:179-186

Leboulanger C, Oriol L, Jupin H, Descolas-Gros C (1997) Diel variability of glycolate in the eastern tropical Atlantic Ocean. Deep-Sea Res 44:2131-2139

Lee C, Wakeham S (1988) Organic matter in seawater: biogeochemical processes. Chem Oceanogr 9:1-41
Lindell MJ, Graneli W, Tranvik LJ (1995) Enhanced bacterial growth in response to photochemical transformation of dissolved organic matter. Limnol Oceanogr 40:195-199

Martin JM, Dai MH, Cauwet G (1995) Significance of colloids in the biogeochemical cycling of organic carbon and trace metals in the Venice Lagoon (Italy). Limnol Oceanogr 40 $119-131$

Mopper K, Stahovec WL (1986) Sources and sinks of low molecular weight organic carbonyl compounds in seawater Mar Chem 19:305-321

Mopper K, Zhou X, Kieber RJ, Kieber DJ, Sikorski RJ, Jones RD (1991) Photochemical degradation of dissolved organic carbon and its impact on the oceanic carbon cycle Nature 353:60-62

Moran MA, Zepp RG (1997) Role of photoreactions in the formation of biologically labile compounds from dissolved organic matter. Limnol Oceanogr 42:1307-1316

Moran SB, Yeats PA, Balls PW (1996) On the role of colloids in trace metal solid-solution partitioning in continental shelf waters: a comparison of model results and field data. Cont Shelf Res 16:397-408

Obernosterer I, Herndl GJ (1995) Phytoplankton extracellular release and bacterial growth: dependence on the inorganic N:P ratio. Mar Ecol Prog Ser 116:247-257

Ogawa $H_{1}$ Ogura $N$ (1992) Comparison of two methods for measuring dissolved organic carbon in sea water. Nature 356:696-698

Poolman B, Driessen AJM, Konings WN (1987) Regulation of solute transport in Streptococci by external and internal $\mathrm{pH}$ values. Microbiol Rev 51:498-508

Sharp JH (1973) Size classes of organic carbon in seawater Limnol Oceanogr 18:441-447

Smith RC (1989) Ozone, middle ultraviolet radiation and the aquatic environment. Photochem Photobiol 50:459-468

Strome DJ, Miller MC (1978) Photolytic changes in dissolved humic substances. Verh Int Ver Limnol 20:1248-1254

Theocharis A, Georgopoulos D, Lascaratos A, Nittis K (1993) Water masses and circulation in the central region of the eastern Mediterranean: eastern Ionian, south Aegean and northwest Levantine, 1986-1987. Deep-Sea Res II 40: $1121-1142$

Thingstad TF, Rassoulzadegan F (1995) Nutrient limitations microbial food webs, and 'biological C-pumps': suggested interactions in a P-limited Mediterranean. Mar Ecol Prog Ser 117:299-306

Thurman EM (1985) Organic carbon in natural waters amount, origin, and classification. In: Thurman EM (ed) Organic geochemistry of natural waters. M Nijhoff/W Junk, Dordrecht, p 7-65

Tranvi.k L, Kokalj S (1998) Decreased biodegradability of algal DOC due to interactive effects of UV radiation and humic matter. Aquat Microb Ecol 14:301-307

van Veen HW (1997) Phosphate transport in prokaryotes: molecules, mediators and mechanismns. Antonie van Leeuwenhoek 72:299-315

Wetzel RG, Hatcher PG, Bianchi TS (1995) Natural photolysis by ultraviolet irradiance of recalcitrant dissolved organic matter to simple substrates for rapid bacterial metabolism. Limnol Oceanogr 40:1369-1380

Wilkinson L (1990) SYSTAT: the system for statistics. SYSTAT, Inc, Evanston, IL

Wright RT, Shah NM (1975) The trophic role of glycolic acid in coastal seawater. I. Heterotrophic metabolism in seawater and bacterial cultures. Mar Biol 33:175-183

Zweifel UL, Norrman B, Hagström $\AA$ (1993) Consumption of dissolved organic carbon by marine bacteria and demand for inorganic nutrients. Mar Ecol Prog Ser 101:23-32 